\title{
Social Capital and Social Transformation in Russia*
}

\author{
Heiko Schrader ${ }^{* *}$
}

Social capital is a valuable resource that can be raised and destroyed, and its level in society is path dependent and related to society's "collective memory" of experience with power structures. Social capital is found both on the network as well as society levels, and a relation between these exists. Fragmented societies with strong, exclusive network ties among the segments and clear-cut dual (inner and outer) moralities often lack strong inherent social capital. Informal norms of action superimpose formal ones and make the functioning of newly implemented institutions dysfunctional. They change very slowly. Russia seems to have performed the transition to a market economy but not to a market and civil society, because social capital on the societal level is rather weak, while it has remained rather strong on the personal network level. The structure of social space of personal relations is opposed to the structure of societal space as solidary civil "community".

Sozialkapital ist eine wertvolle Ressource, die sowohl erzeugt als auch verbraucht werden kann, dessen Position in der Gesellschaft richtungsabhängig und verankert im Kollektivgedächtnis der Erfahrungen mit Machtstrukturen ist. Sozialkapital kann auf der Netzwerk und auf der Gesellschaftsebene gefunden werden, wobei eine Relation besteht. Fragmentierten Gesellschaften mit starken, exklusiven Netzwerkverbindungen innerhalb der Segmente und einer ausgeprägten dualen (inneren und äusseren) Moral fehlt es oft an starkem innewohnendem Sozialkapital. Informelle Normen überlagern formelle und setzen die Funktion von neu implementierten Institutionen ausser Kraft. Sie ändern sich sehr langsam. Russland hat sich scheinbar in eine Marktwirtschaft umgewandelt, aber nicht in eine Markt- und Zivilgesellschaft, weil das Sozialkapital auf der Gesellschaftsebene eher schwach ist, wohingegen es auf der Netzwerkebene eher stark ist. Die Struktur des sozialen Raumes in persönlichen Beziehungen befindet sich im Gegensatz zu der Struktur von sozialem Raum in einer solidarischen Zivilgemeinschaft.

Keywords: Transformation / social capital / trust / double morality / Russia

* Manuscript received: 15.01.04, accepted: 18.03.04 (1 revision)

** Heiko Schrader, Professor, Institute of Sociology, Otto-von-Guericke-University of Magdeburg. Main research interests: Social studies. Corresponding address: Heiko.schrader@gse-w.uni-magdeburg.de 


\section{Introduction}

Market societies of Western Europe, their rationally acting institutions and organizations, and the politico-economic framework in which they can function efficiently emerged in a process of longue durée (Braudel) of economic and social change and modernization (Goetze 1997). Modernization theory assumed that this historical process was a blueprint, occurring with a time lag in nonWestern societies, which would eventually catch up with the West. With the collapse of the planned economies of Eastern Europe it was assumed that a short-term institutional systemic change - a transition - would lead the former socialist societies back to Europe (Olson 1995; Poznanski 1995; Zloch-Christy 1998). Based on a development strategy of structural adjustment, institutions should be implemented according to the Western example, constituting the basis for a self-adjusting market. The keywords here are the model-transfer concept and designer capitalism (Kollmorgen/Schrader 2003)

Such an orthodox perspective of transformation implies a relatively short and difficult transitional period of structural adjustment (topics such as 'shock therapy' were applied), followed by incorporation into the world market and positive effects for economy and society. The author of this paper takes a different stance. He argues that transformation is not a short-term project of transition, but a long-term process of modernization. This process in Eastern Europe has certain unique characteristics, which engendered a particular lowtrust culture in the public realm as opposed to a high-trust culture in the private realm. The long-term nature of transformation is closely related to slow change in patterns of action, attitudes and opinions, and norms and values, which engender institutions and their functioning.

In the first part of this paper I shall argue in favour of a transformation research that considers transformation as path dependent from the specific, sociostructurally embedded typical patterns of meaning, action and behaviour that emerged during, if not even before, the Socialist period and continues to impinge upon post-socialist Eastern Europe. With the issues of trust and social capital I will discuss two closely related concepts in the second and third parts of this paper, which can be applied to both individual and societal levels. I will argue that in societies, characterized by closed personal networks (strong ties according to Granovetter), and which are lacking weak ties to other networks, two distinct cultures of trust and social capital emerge: a low-trust culture (or lack of societal social capital) in the public realm and a high-trust culture or high societal social capital in the private realm. This structuration (Giddens) directly impinges on social and economic interaction and on the transformation process in Eastern Europe.

The last part of this paper will illustrates the theoretical discussion with the case of Russia - that country which experienced the longest and most severe socialist period. I shall argue that, in spite of severe changes of action in post-Soviet 
Russia, particular structurations occurred, and actions can be observed in everyday-life, which are outcomes of pre-Socialist times and have continued to exist - although in different settings and with different shapes - since the Soviet Period.

\section{Transformation Research and Transformation}

In comparison with an orthodox understanding of transformation research that has been shaped by neo-liberal economists and political scientists and considers the post-1990 events in Eastern Europe as a systemic transition from socialism back to capitalism, the institutionalist approach takes a more differentiated stance. Actions and behaviour of individuals, as well as the functioning of institutions, are path-dependent (North 1981; 1990). ${ }^{1}$

Concerning path-dependencyl argue that, while the model-transfer concept identified a number of technocratic development constraints on the political and economical levels, it neglected people's experienced social time':2 individual, biographic experiences, personal attitudes and opinions, as well as collective experience and a society's 'collective memory' (Durkheim 1984) that has engendered a unique structuration (Giddens) ${ }^{3}$ and culture ${ }^{4}$ that even nowadays plays a significant role in everyday life (Hann 2002). From such a perspective,

1 According to North (1990; 1991:97), institutions are self-imposed limitations of individualsthat constitute the rules of the game of societies, and aim to achieve higher utility by means of cooperation. Together with other constraints, such as scarcity, institutions provide the scope for action. Normative rules constitute the framework of economic action, and can be formal and informal. It is important for the efficiency of economic systems that formal and informal rules match each other, because only then do people voluntarily keep to them. Franzen, Harland and Niessen (2001:22) underscore the importance of informal norms in the transformation process, because these do not quickly change with the formal ones. In line with these scholars, I shall take the cleavage between formal and informal loans as an indicator of transformation failure.

2. The term of social time in cultural sociology implies that time is measured according tosocially relevant events, and organized accordingly (cf. Braudel 1981). These events shape the socio-cultural memory of individuals and collectivities.

3 According to Giddens (1979) structuration expresses the mutual dependency of humanagency and social structures. He argues that social structures are intimately involved in the production of action. The structural properties of social systems provide the means by which people act and they are also the outcome of such actions

4 In line with Tetzlaff (2000:27-28) I consider 'culture' as a memory of collective experience a system of standardized orientations toward recurrent problems. With their culture people obtain a subjective perception of themselves and a 'fictitious differentiation' from 'others' and 'alien' environment. From such a perspective, culture provides a dense net of meaningful structures surrounding the individual and has formative influence on his or her action and behaviour by means of habitual perception, based upon socialization. 
the historical period of socialism (which was not only of different lengths but also different intensities), the type of system change to and from socialism, the present perception of the socialist period, and present and former relations to the Soviet Union and other socialist countries have a similarly sustainable influence on institutional change and development in the post-socialist period as the self-perception of asymmetrical centre-periphery relations.

Taking this stance, Stark (1992a; 1992b; 1992c) and Staniszkis (1991) were very critical of neo-liberal prognoses of Eastern European development: a short hard slog of the shock therapy, followed by rapid emergence of a market economy and market society. They feared that a 'continuity in change' might occur, which engendered a specifically Eastern European type of capitalism, by nature fundamentally different from the Western type.

Subsequent events have supported this view. More than 10 years after the collapse of socialism, the former production industries are still unproductive or have closed down. Growth rates are dependent more on the service sector than on production, and development prognoses for a number of Eastern European countries are still poor. For most people, living conditions have not improved or have improved only slightly, while post-perestroika supply and advertisement of goods produce income inequality and budgetary deficits. In everyday and business life, interaction with the bureaucracy is characterized by corruption. Criminal organizations use blackmail to extort protection money and control large sections of the economy. Nepotism and patronage hamper the emergence of a performance principle etc. In other words, the development of economy and society is hampered not by the absence of particular modern institutions - such as administration, police or jurisdiction - but by their insufficient functioning in the sense of rational bureaucracy and their calculability and operation according to principles of rule of law, formal equality, secondary liability and efficiency. Many spheres of public administration, governance and jurisdiction are characterized by arbitrary bureaucratic decisions, perversion of justice, venality, and low moral and ethical standards. Even public security, public goods and public services have been commoditized and can often be acquired only by means of additional informal payment or patronage. ${ }^{5}$ On the basis of my own

5 While the accumulation of means of production is considered normal, Elwert (cf. Elwert 1987) identified another type of accumulation: venal accumulation. He argues that terms like corruption or bribery conceal the general pattern of commoditization of public goods and services in a number of developing societies, to which I would also add transformation societies. 
research findings ${ }^{6}$ I shall argue that market society in some Eastern European countries is not only functioning inadequately - as the World Bank and IMF state - but that it has been perverted by the consistent expansion of venality and commoditization to almost all spheres of life, and by having lost its moral embeddedness.

The process of privatization of state property was particularly observed under the aspect of the emergence of property rights as a necessary constituent of market society. A number of scholars discovered specific hybrid forms of entanglement between policy, bureaucracy and the economy for Eastern Europe (Åslund 1995; Stark 1994). Jadwiga Staniszkis (1995) termed this phenomenon 'political capitalism', a hybrid societal formation and institutional modus of restructuring socialist societies under conditions of peripheral position. This type of capitalism still functions according to the logic of socialist systems). It possesses a logic of reproduction of power and dependency fundamentally different from the logic of accumulation of capital, but adapted to function under capitalist conditions. For characterizing the type of capitalism in Russia other scholars even applied the term 'Mafia capitalism' (Hessinger 2001; Varese 1994). Both concepts demonstrate an understanding of post-socialist path dependency. However, while the terminology chosen relates to an understanding that these developments constitute a departure from the norm ('Western European capitalism' or 'democratic capitalism' (cf. Tatur 1998)), I shall argue that, from a global perspective in purely quantitative terms, such types of capitalism constitute the norm, while 'democratic capitalism' provides the exception. Following Christophe (cf. Christophe 1998) I argue that under the particular conditions of Eastern European capitalism, the observed pattern of behaviour of economic agents is rational. ${ }^{7}$ I consider the specific, sociostructurally embedded typical patterns of meaning, action and behaviour that correlate with the functioning of institutions to have emerged path dependently.

6 Following my research on pawnshops and poverty in Saint Petersburg/Russia (cf. Schrader 2000a), I am conducting research on small business in the Czech Republic, Bulgaria and Russia, in collaboration with Eckhard Dittrich and a research group from the three countries. Although the level of corruption - and particularly payment of protection money - seems to have decreased, it nevertheless constitutes an important factor in business life, and ought not to be neglected.

7 According to Christophe (1998: 201), the logics of action and preferences of socioeconomic actors decisively depend on the institutional context in which they are embedded. She argues that the general assumption of rational economic action based on cost-utility reflections is the contingent result of successful institutionalization of market pressure and property rights, which do not exist against the background of weak states. 


\section{Personal Trust}

Every society experiences basic problems of social order to engender a minimum of stability, social peace and external security, out of which emerge further patterns of Vergesellschaftung (building civil society). Central to this is the problem of trust. In recent discourse, trust takes on the function of a remedy. It is said to "contribute to economic growth and efficiency in market economics, to the provision of public goods, to social integration, cooperation and harmony, to personal life satisfaction, to democratic stability and development, and even to good health and longevity. Trust is also at the centre of a cluster of other concepts that are no less important for social science theory than for practical daily life, including life satisfaction and happiness, optimism, wellbeing, health, economic prosperity, education, welfare, participation, community, civil society, and democracy. And of course, social trust is a core component of social capital, and is normally used as a key indicator of it, sometimes as the best or only single indicator" (Delhey/Newton 2003). I will start with some general considerations of trust, and then consider the relation of trust and social capital.

In social science, both the metaphysical and philosophical dimensions of trust have been deconstructed by referring to its function in personal relations and within society. Luhmann (1988), for example, interpreted trust as a mechanism to reduce insecurity and risk in a very complex life world. From an angle of synergetics, Haken (1992) referred to an emergence of 'situational competence' to cope with uncertainty and complexity. Analytically considered, trust is particularly context and time dependent. Decision theory and game theory have taken the actor's subjective point of view by applying different contexts and time horizons (Axelrod 1984; 1986). In the typical exchange model in the anonymous market, the situation of transaction is such that we never see the opportunistic agent again. Thus, the risk of being disappointed is high, and we are therefore cautious, because this single transaction is not based on previous experience with the exchange partner. In such a situation, functioning contract law can, to some degree, act as a substitute for trust in the integrity of a person, and considerably decrease risk. With repeated transactions, trust is an outcome of positive experience. On the one hand, it refers to the past: We obtained our own or others' information on this agent. On the other hand, it refers to the future: The person with whom we interact will be interested not to lose his or her reputation, and will also share the benefits from being trusted. Interacting with known, reliable people reduces the risk level, particularly in situations in which high risk and insecurity characterize the social and economic environment. Furthermore - and this will be important for my argumentation people's continued experiences of past rewards and disappointments in situations in which trust was required will strongly influence their ability to provide trust advances to others. 
The investigations of decision theory and game theory explain people's motivation to trust each other by opportunistic motives. Trust is substituted by experience, probabilities and mutual interdependence of utility. These theories do not neglect culture in general, but see it as external to their models. Many sociologists view such approaches as useful, but nevertheless insufficient and 'undersocialized', because rational action provides only a small part of social reality, and methodological individualism does not fit for an explanation of social phenomena. Some authors are close to Rousseau in saying that basic or fundamental aspects of trust are a precondition for human interaction in general (Durkheim 1984; Giddens 1990; Misztal 1996). Binding social norms 'thicken' into institutions that determine action and behaviour. According to their sphere of effect, they can provide limitations as well as opportunities. Moral economies $^{8}$ are certain spheres of life that are strongly normatively regulated, have narrow binding rules and mutual expectations with regard to reciprocity and redistribution within the group. Economic anthropology showed that moral economy is not as homogeneous as assumed by investigating the sphere of activity of reciprocity norms, relating it to social and geographic space, and showing that in pre-modern societies the degree of reciprocity decreases with social distance. We can also apply this to modern societies, and we find the same assumption in network theory, and in the sociology of organization. In terms of the latter, a moral economy in pre-modern societies restricts choice, while a network moral economy provides an alternative to market and hierarchy: Trust, mutual obligations and social control within the network sphere help to reduce the high transaction costs of hierarchy (organizational structure) and market (risk, contracts, monitoring opportunism, moral hazards. Strong ties, however, may at the same time engender insurmountable boundaries, when we put our emphasis on the two distinct spheres of inner and outer morality. To paraphrase Granovetter (1977) the "weakness of strong ties" in such networks is their tendency to be exclusive. Here morality becomes contextual, and a "cognitive systematization of the social environment according to binary patterns" occurs (Tatur, 1998: 354).

8 Strong normative relationships between individuals or groups constitute 'moral economies', which subjugate individual action to socially binding norms. Contrary to older approaches - which in the tradition of Gemeinschaft vs. Gesellschaft take 'moral economy' as the antonym of 'market economy' - scholars nowadays consider this concept from an actor-oriented perspective to apply it to different spheres of economic life that are morally constrained and exist side by side with market-rational action (Booth, 1994).

9 Mark Granovetter investigated strong and weak ties from the perspective of network theory. The 'strength of weak ties' is their ability to open up closed networks by building bridges to other networks. Recent approaches applying Granovetter's distinction to the notion of social capital distinguish 'bonding capital' (between people) and 'bridging capital' (between groups). 
There are a number of concepts in sociology that refer to these morally distinctive spheres. An extreme case provides the fragmented morality of 'amoral familism' (Banfield 1958) - a dual morality with unconditioned trust within the network (based in this case upon ascriptive familial relations) turning into strong distrust and a general readiness to exploit others outside the network. Less extreme, for example, is the form of 'familism' (Fukuyama 1995; 2000). Common to these specific relations is that they aim at simplifying social complexity and reducing risk and uncertainty by putting the personal identity of the interaction partner into the foreground, setting formal equality out by certain preferences grounded on particular criteria (such as kinship or friendship), and regulating the preference order by norms. To put it another way, this type of social relations stands against the emergence of a societal space, because segmented personal spaces with clear-cut boundaries, different moralities, and scopes of personal action cannot be overcome.

These distinct spheres of morality are one crucial element in the conceptualization of pre-modern and modern patterns of trust. In pre-modern settings, social action is organized according to binary and antagonistic perceptions; trust is a very personal and emotional affair and can only be considered in contrast to distrust. Social relations are structured according to these binary categories, and there is no place for a third, more neutral category of indifference. As Giddens (1990) emphasized, this third category, has become increasingly important for the functioning of modern societies. Indifference means to take a more neutral stance and to de-emotionalize ones actions and social relations. People do not categorize alter as either friend or enemy, but take an impersonal stance. More important than his personal attributes become his functional ones, because people know that they can rely on the institutional framework rather than on their individual power to regulate affairs in case of being disappointed.

\section{System Trust and Actor-Centred Social Capital}

Characteristic of modern, reflexive societies is 'system trust' (Luhmann 2000). Trust in state institutions and the economy is based on experience of the predictability of institutions - which function according to criteria of rule of law, formal equality and secondary liability - on experts, on 'certificates', and on a stable currency in particular. Only with these preconditions can 'face-toface' relations (Giddens 1990) - the criteria for which are good knowledge of and experience with the interaction partner, one's own efficient sanction mechanisms and the public pressure of the moral economy - be supplemented by 'faceless' relations (ibid.). These function without either party needing a personal guarantor, because both interaction partners can assume that they both usually adhere to rules and laws (Christophe 1998:210), and that state institutions negatively sanction offences. From an actor-theoretical perspective, 
system trust offers new scopes of action. As a concept, system trust is closely related to the institutional framework; for transformation research, system trust is implemented by 'institution building' according to design. To some degree, system trust may substitute personal trust.

A bottom-up perspective examines the concept of social capital at the level of society, which considers trust the property not only of individuals, but also of itself. According to Hardin (1996), trust is a product of individual experience. We constantly modify and update our trustful feelings, and these add up to a climate of trust within society. From the empirical point of view, this means that levels of 'generalized trust' reported in societies are an indicator of the trustworthiness of the society, as Putnam (2000:138) argues. Simply speaking, social capital constitutes an asset, which results from social relations. While on the network level it may positively affect ones own career (the perspective that Coleman (1988) takes), it is also assumed to impinge upon the development of entire societies. Thus, during the last decade this concept has experienced great prominence not only among social scientists, but also among development organizations. The World Bank described it as "the missing link" in development (Grootaert 1997), and has made extensive use of Robert Putnam's Making Democracy Work: Civic Traditions in Modern Italy. Putnam argues that "trust, norms and networks can improve the efficiency of society by facilitating coordinated action" (Putnam 1993:167). He relates development and lack of development to the level of civic involvement in society, and this level is culturally grounded. According to John Harriss, the main problem with both Putnam's and the World Bank's considerations of social capital is that they reflect a trend in social science "that systematically obscures power, class and politics" (2001:2). Social capital, trust and civil society are topics that lack a political dimension and power structures.

I agree with Harriss, and will try to bring a political dimension to the concept of social capital. I will start from Francis Fukuyama's (1995:21) perspective (to which Harriss does not refer). Fukuyama also considers social capital as an important factor for a nation's welfare and competitiveness. He defines social capital as a given set of informal norms and values that all members of a group share and that facilitate cooperation between group members.

According to Fukuyama, the ability and capacity to communicate in an uncomplicated way and to cooperate is 'spontaneous sociability', which constitutes an important part of social capital and plays a crucial role in the creation and maintenance of civil society, because spontaneous sociability enables people who do not know each other to congregate and cooperate with each other. But where this 'spontaneous sociability' comes from, and why it is lacking in other societies, are questions that remain open. 


\section{The Relationship Between Actor-Centred and Society-Inherent Social Capital}

How then can we describe the relationship between actor-centred social capital and society-inherent social capital? In my view, so-called 'low-trust societies' (cf. Putnam) are not societies that lack trust in general, but rather societies that have strong, context-related particularistic moralities. However, social capital exists within the boundaries of these moralities, not across them, and it is to this that the concepts of 'familism' and 'amoral familism' refer. There are manifold examples of how the clear-cut distinction between inner and outer morality, norms and values negatively impacts on societal cooperation and solidarity. Negative effects on governance and economy are discussed with the examples of bribery and corruption: They demonstrate that social capital is as valueneutral as physical capital, but that its application can engender societal benefits, as well as damage.

My interpretation of Fukuyama is that he does not understand culture in a primordial way (as Putnam does), but as a collective experience of social time: a 'collective social memory', which is passed on to subsequent generations (Fukuyama 2000:195, 237). According to Fukuyama, society-inherent social capital is not a valuable cultural property of some 'higher cultures', but is rather in a continuous process of change, construction, destruction and reconstruction by people, institutions and organizations, governments and ideologies. This means that social capital manifests itself - and constitutes a valuable resource on the individual, network, and socio-cultural levels. It can be kept in good condition, but it can also get lost; it can be very strong on the actor-centred network level, and at the same time very weak on the societal level.

The expectations of 'designer capitalism' constitute a successful interlocking of the framework of society (laws, institutions, and basic principles of formal equality, equity and property rights) with culturally determined social capital. If there is a lack of social capital, Fukuyama argues, it can be compensated to some degree by formal mechanisms of control, such as contracts, hierarchies, constitutions, legal norms, etc. However, the greater this compensation is, the higher are the transaction costs. This perspective can be applied to the failure of true socialism, as will be seen later in this article.

We now return to Harriss' critique of the concept of social capital lacking a political dimension: When we assume a path-dependent 'cultural heritage' that reflects individual and collective experience of trust advances - to others, the state that the economy - manifests itself in informal norms, as well as in the degree of spontaneous sociability, I shall argue that this view of structure-actor dynamics (structuration) also includes a political dimension. Experience manifests itself in specific individual and collective modes of action and behaviour, expectations and attitudes toward the environment, the state, the market, and the like. Norms, values, attitudes and modes of action are passed on 
to the next generation. With a time delay, they in turn influence social structure, and a change in social structure may again result in changing experiences and changing norms, values and modes of action. However, these structure-actor dynamics are much slower than politically intentioned systemic institutional transfer. The temporary non-compliance of formal and informal norms results in institutions being dysfunctional, because people both in them and interacting with them continue to behave according to their informal norms, rather than adapting the formal norms.

From this perspective, post-socialist societies may have executed the politically intentioned transition to a market economy, but have yet to make the transformation into a market society. The latter implies that people behave as in a market society, and feel part of it. This presupposes not only the existence of the institutions of a market economy, but also the emergence of institutional trust, system trust, and society-inherent social capital, so that people can choose between the market (faceless transactions) and networks (more personal relations) according to the criterion of transaction costs.

To reiterate, I would like to summarize the relations just mentioned. The implementation of market institutions and constitutional institutions in the course of model transfer in Eastern Europe does not automatically engender a functioning market society. This can be explained as follows:

Social capital on the level of entire society is weak compared with social capital based on personal networks. The structure of social space of personal relations hampers the emergence of a societal space of solidarity-based and civil Gemeinschaft, and influences the functioning of both old and new institutions. It must be emphasized here that institutions do not act independently, as New Institutional Economics assumes, but that their functioning decisively depends upon the action and behaviour of actors within them and others interacting with them.

For the same reason, hierarchical implementation of a functioning market society is very difficult, and entails enormous costs.

\section{Path Dependency and Social Capital in Russia}

The discussion so far has been theoretical. Now I shall apply the foregoing theoretical concepts to Russia, examining relationships between power relations and low and high trust).(delete this section). In transformation sociology, path dependency is usually applied to the transition from the socialist to the postsocialist period, but I shall consider a longer period - from the prerevolutionary period to the present. I shall begin with the notion of 'Soviet man' and the Soviet period, then step back in history, and finally conclude with my own observations from recent years. 
Levada (1993) considers the abrupt change from feudalism to socialism as a 'social experiment', which, in both ideological terms and everyday life, engendered a 'Soviet pattern of life' - a culture and civilization that was perceived to be self-generated, viable and superior (Arnason 1998:28). With this came 'Soviet man' as the enforced dominant social type, at the expense of the elites and intelligentsia, engendered during the Stalin era by state control of education and media, and by terror and liquidation.

The title of Levada's book, Sovetskii prostoi chelovek [Soviet Common Man], already points at the specifics of Homo sovieticus. He is the antithesis of individualistic Homo oeconomicus: a 'mass man', de-individualized, 'vitreous', frugal and easily governable. All these characteristics were projected - and politically defined - norms that, however, emerged as a characteristic of people and society (ibid.).

A peculiarity of Homo sovieticus was that he believed himself to be unique and different to people of other times and social systems. He considered himself to be outstanding, with a higher value system, consciousness of his own superiority, and a system of social measures and interpretations incomparable to other social systems (ibid: 16). ${ }^{10}$ Thus, the distinction between 'own' (Soviet) and 'alien' (capitalist), was an important structuring element both in ideology and everyday life. In the course of assigning difference between these two ways of living, certain ambivalences emerged: ones own was not always better and superior, but could also appear in form of "social-masochist self-humiliation" (ibid: 17; (cf. Witte 1997).

During the post-Stalin era, Homo sovieticus went into terminal decline, both as an ideal type and as a reality. In the late 1980s, Levada argues, he could still be found among the older, rural-based, poorly educated generation; the middle generation experienced a conflict and decay of the typical characteristics, while the young generation consciously dissociated itself from them (ibid: 262f., 290f.).

While Levada's analysis considers the psychological characteristics of Soviet society as a result of political will and psychological pressure, other scholars treat the Soviet period as a deepening of already existing structures from the pre-socialist period (Veselov forthc.). Although the country had some industrial centres at the dawn of the revolution, some authors consider Soviet society to have emerged directly from feudal peasant society, which was centrally administered but with the center and the appropriating elite spatially and

10 This became visible in his consciousness of social time - the October Revolution of 1917 as a watershed, his geopolitical orientation (the Iron Curtain), socio-psychological boundary between 'own' and 'alien', axiological points of reference (own value system) and aesthetic, ethical and epistemological orientation (distinct criteria of truth and beauty) (ibid.). 
socially far distant from the rural population. Feudalism, with structures of serfdom characterized by strong feudal dependence, officially existed until 1861.

One issue I can address here only briefly is linked to discussions of the Russian mentality and national character. In this context, scholars repeatedly refer to Russian traditional self-sufficiency. The geographical vastness of Russia stood in opposition to the rural population's narrow social space. Centuries of exploitation by aristocrats and kulaks (wealthier peasant farmers) affected the small peasants, who patiently bore their destiny. ${ }^{11}$ The peculiar mix of lack of responsibility for ones own destiny, of clientelism and patronage, of very close trust relations on the personal level, and of simultaneous distrust of the state and the elite can therefore be considered a continuation of pre-revolutionary structures, as well as a result of the political system in the Soviet Union.

Let us now go beyond this typically Russian discourse on 'national character' and 'Russian (or Soviet) mentality' and approach our topic, social capital, from the perspective of social space. Fjodorov and other scholars emphasize a clearcut distinction between public and private space. Behaviour and action in the public space was characterized by opportunism, which was rooted in feudalism and took a specific form during the Soviet period. Because of the deep distrust of central and political authorities, people demonstrated a 'hypocritical' obedience, which was reversed in the private sphere. As Fjodorov (1993:38-39) argues, the constraint to be double-tongued corrupted people. Children learned to talk about issues in an accepted way, although in truth things were totally different. This condition was disastrous for people's morality on all system levels.

The different moralities that affected U.S.S.R.-inherent social capital are important with regard to our topic. Fjodorov (ibid: 41) argues that these antagonistic moralities were one of the reasons for the failure of socialism. Public goods were not considered communal, but the property of the state that could be appropriated illegally. In this way public goods were not considered as such, but were personally appropriated. The entire Soviet Union was a large 'self-service' shop in which everybody took what they could get. Such behaviour was considered legitimate, and those who were less successful than others were considered stupid. People referred with self-irony to the superiority of socialism, because capitalism would not have been able to cope with such a condition. Of course, not all of the political or economic class was corrupt, but it became more and more obvious that people valued personal interest higher than their duty and acquiring the privileges of the elite.

11 Fjodorov (1993:116) compares the Russian peasant with a sheep shorn so often through the centuries that its wool hardly grew again. This is how he explains the passivity within the Russian national character. 
In addition to this public-private divide, I would like to refer to another structuration of social space and personal relations (cf. Schrader 2000b). During my two-year stay in St. Petersburg in the late 1990s, I recognized a frequent use of the terms nash (ours) and ne nash (not ours) in colloquial language. While this distinction, which refers to the social distance of alter, is common in many languages, it acquired a particular connotation in the Soviet Union. Originally, it was used in the official public sphere to denote system-compliant and systemantagonistic action during the Soviet period. In the informal public or private spheres (Zdravosyslova/Voronkov (2002) the term experienced a reverse connotation: Ne nash became a synonym for potential political 'snitchers', but also for all those whom it was better not to trust, while nash characterized trustful personal relations. Beyond that, the world of nash also acquired an economic connotation, because it was related to ones own provisioning networks. Thus, the worlds of nash and ne nash were two opposed spheres of morality, with no third sphere of indifference: Everyone whom one did not know became subsumed under ne nash. In addition, Srubar (1998:82) mentions that norms of social solidarity and reciprocity of obligation were valid only within ones own social networks, and that the code of conduct was also to use ones own position at work or within an institution to exploit or misuse them for the sake of the members of ones own network. This concrete fear of political spies has been lost during the late socialist and post-socialist periods, but the perception of the life world as two opposed spheres has been maintained.

I argue that due to insecurities in life - and particularly due to an insufficiently functioning institutional framework - people rely on and cultivate their social capital, which is hidden in the social network of nash, instead of taking the risk of faceless transactions. My hypothesis is that, in spite of a rapidly growing market economy in Russia, people's interactions, transactions, and spheres of trust are in many cases still limited to their rather closed social networks, which are based upon reciprocity, but which have a redistributive function within society for the sake of one's networks. Loyalty and solidarity are often limited to these networks, which typically have organizational patterns based on kinship, ethnicity, local origin, shared history in school years, university, or military service. Leading figures in politics, economics and administration recruit close colleagues from their personal networks, because this supports their own position and generates confidants. The boundary between nash and ne nash marks the outer boundary of reciprocity and inner morality. The cohesiveness of solidarity remains limited to nash and is even counterproductive, because moral barriers outside ones own networks are rather low.

This segmentation of social space is not necessarily relevant in the anonymity of everyday life. The stranger becomes an ignored person of whom one catches a glimpse but with whom one does not interact; this is a pre-condition for peaceful cohabitation (Giddens 1990). However, the stranger "who comes today 
and stays tomorrow' (Simmel (1971) becomes a problem, because then people have to place him or her in either of these two spheres as nash or ne nash. This happens, for example, in kommunalki (communal apartments), which still exist and which constitute the precise opposite of Gemeinschaft in Tönnies' sense. They are battlefields to achieve a minimum of privacy and intimacy, places of class conflict, snitching and denunciation for personal benefit.

This characterization should not imply that people are basically unable to engender communicative relations with unknown people. On the contrary the boundary between the two spheres of morality can quickly be adapted to the circumstances - for example, on long train journeys through the vastness of Russia, when unknown travellers are involuntarily put together in a compartment, but quickly generate a confidential atmosphere by sharing food, drinks and life stories. This may seem to be a counter example to my explanation pattern, but it can actually be interpreted in such a way that the negative connotation of ne nash forces the actor to temporarily co-opt ne nash in situations of spatial narrowness. However, this co-option is much easier for 'a stranger who will leave tomorrow'.

The structures that other scholars and I describe here hinder the emergence of the structures of civil society and society-inherent social capital, because they are based upon personal loyalty and/or opportunism, and characterize the whole public sphere. A jointly pursued goal across ones own network boundaries is difficult to achieve. ${ }^{12}$

\section{Conclusions}

In this paper I began that mainstream approaches of short-term transition are inappropriate in so far as cultural aspects of transformation have been neglected. Structuration processes even before, but particularly during, Soviet times have engendered a peculiar double morality that has to be overcome for system change in Eastern Europe to be finally successful. I further argued that this double morality is related to a clear-cut segmentation of society into personal, actor-centred networks with strong actor-centred social capital and a tough moral economy, but at the same time a perception of society beyond these networks as potentially hostile.

A successful transformation into a market society, however, means that not only institutions of market societies exist, but these function like in market societies. To achieve this, one important factor is that people develop generalized and systematic trust, and society-inherent social capital, which so far only exist in

12 An example is provided by buildings of privatized apartments. Although the owners invest their apartments, they do not form an owners' community that invests in the staircases, which still belong to the state 
basic form. From the perspective of network theory, strong ties within personal networks have to be linked with weak ties - or bridges, according to Burt (1992) - between different networks. Only then civil society can emerge understood as a social structure where people also beyond personalized relations congregate and strive for a common good or interest.

The obvious question is how to overcome this dilemma of bilateral relatedness of action and social structure. The answer that I provided is the question of what causes basically the hen-and-egg problem. My understanding of structure-actor dynamics is that the approaches have to live this dilemma, because on one hand action it is embedded in, or an outcome of, social structure, on the other hand it engenders social structural change. The solution to the dilemma in these approaches lies in the time factor - or more precisely: slowly changing 'individual' and 'collective memories' - will cause a gradual change of social structure. And this change emerges from the experiences in everyday life in contact with market, working place, bureaucracy, politics, communication systems, education systems, and the like. I therefore applied the term 'socialization' to express this gradual process. Changing experiences will in the longer run result in changing attitudes, norms, and values.

Various scholars have already observed this change. Srubar (2001:63-64) emphasizes that a new differentiation of social positions has occurred in the course of transformation, directly influencing life chances and changing social structure. As in Western societies, socio-economic differentiation has occurred that has increased social distance and has broken up formerly personal networks and relations. Of course, it is always very tempting to apply a typology for an entire region with historical similarities, talking about post-socialist pathdependent development (whereas the term 'post-socialist' already pre-supposes such a path-dependency) and path-dependent cultural space. However, when we leave the theoretical level and consider empirical cases we should be aware that Eastern Europe (in the same way as Western Europe) does not constitute a homogeneous entity. Different countries experienced different development paths and structuration processes, in spite of the same ideological frame of reference. My own research experience from Russia, which probably constitutes the most extreme case because of the longest communist period and a peculiar stance towards this communist past, suggests that Srubar's description particularly holds true for the younger generation, students, and people who have recently entered the labour market: They experienced their youth under glasnost, perestroika and post-socialist conditions.

However, the older generation in particular - and to some degree also the medium generation - strongly refer to and rely on their personal networks. These cut across structures of market and civil society, so that not only with regard to the perception of the life world, but also in practice, action within ones own networks provides a higher degree of security and better results than 
action and transactions in the anonymous market. The clear-cut boundary between two antagonistic spheres of trust: nash and ne nash, also means that one changes sides when one leaves ones networks.For others, one becomes ne nash.

Civil society requires solidarity between people who do not personally know each other but are in the same or a similar social situation, as well as a personal commitment to these interests across network boundaries. Therefore, it is not really astonishing that civil society in Russia is not being created from the bottom up, but rather that already established organizations and institutions which in many cases had their origins in Soviet times -these taking up the rhetoric of civil society to pursue their self-interest, without being supported by a base of solidarity. (Schrader et al. 2000). From such a perspective, the transformation process in Russia is intergenerational. It will not be finished with the implementation of market institutions, but requires longer socialization of the actors.

\section{References}

Arnason, J.P. (1998): Gescheiterte Globalisierung: Das sowjetische Modell, in: Müller, K. (ed.) Postsozialistische Krisen - Theoretische Ansätze und empirische Befunde, Opladen: Leske und Budrich.

Åslund, A. (1995): How Russia Became a Market Economy, Washington DC.

Axelrod, R. (1984): The Evolution of Cooperation, New York: Basic Books.

Axelrod, R. (1986): An Evolutionary Approach to Norms, The American Political Science Review 80, 1095-1111.

Banfield, E. (1958): The Moral Basis of Backward Society, Glencoe, Ill.

Booth, W. (1994): The Idea of Moral Economy, America Political Science Review 88.

Braudel, F. (1981): Civilization and Capitalism, 15th-18th Century. Vol. I: The Structure of Everyday Life, New York: Harper and Row.

Burt, R.S. (1992): Structural Holes. The Social Structure of Competition, Cambridge, MA: Harvard.

Christophe, B. (1998): Von der Politisierung der Ökonomie zur Ökonomisierung der Politik. Staat, Markt und Außenpolitik in Russland, Zeitschrift für Internationale Beziehungen 5, 201-240.

Coleman, J. (1988): Social Capital in the Creation of Human Capital, American Journal of Sociology 94 (Suppl.), 5-120.

Delhey, J./Newton, K. (2003): Who Trusts? The Origins of Social Trust in Seven Societies, European Societies 5, 93-137.

Durkheim, E. (1984): The Division of Labor in Society, New York: Mcmillan. 
Elwert, G. (1987): Ausdehnung der Käuflichkeit und Einbettung der Wirtschaft. Markt und Moralökonomie, in: Heinemann, K. (ed.) Soziologie wirtschaftlichen Handelns. Kölner Zeitschrift für Soziologie und Sozialpsychologie, Sonderheft 28, 301-321.

Fjodorow, R.P. (1993): Wohin geht Russland? Eine Nation am Scheideweg, Bonn: Dietz.

Franzen, W./Haarland, H.-P./Niessen, H.-J. (2001): Transformationsbarometer Osteuropa 2001, Frankfurt/M.: Campus.

Fukuyama, F. (1995): Konfuzius und Marktwirtschaft. Der Konflikt der Kulturen, München: Kindler.

Fukuyama, F. (2000): Der Große Aufbruch. Wie unsere Gesellschaft eine neue Ordnung findet (Titel i.O.: The Great Disruption), Wien: Paul Zsolnay.

Giddens, A. (1979): Central Problems in Social Theory, London: Mcmillan.

Giddens, A. (1990): The Consequences of Modernity, Cambridge: Polity Press.

Goetze, D. (1997): Modernisierung, D. Nohlen et al. (eds.): Lexikon der Politik: Die östlichen und südlichen Länder, München: Beck, 380-384.

Granovetter, M. (1977): The Strength of Weak Ties, in: Leinhardt, S. (ed.): Social Networks. A Developing Paradigm, New York: Academic Press.

Grootaert, C. (1997): Social Capital: The 'Missing Link', in: World Bank (ed.): Expanding th Measure of Wealth: Indicators of Environmentally Sustainable Development, Washington: World Bank.

Haken, H. (1992): Konzepte und Modellvorstellungen der Synergetik zum Gedächtnis, in: Schmidt, Siegfried (ed.): Gedächtnis : Probleme und Perspektiven der interdisziplinären Gedächtnisforschung, Frankfurt/M.: Suhrkamp, 190-205.

Hann, C. (2002): Vorwort, in: Hann, C. (ed.) Postsozialismus. Transformationsprozesse in Europa und Asien aus ethnologischer Perspektive, Frankfurt/M.: Campus, 7-10.

Hardin, R. (1996): Trustworthiness, Ethics 107, 26-42.

Harriss, J. (2001) Depoliticizing Development. The World Bank and Social Capital, New Delhi: Left World Books.

Hessinger, P. (2001): Mafia Capitalism or Civil Society?, in: Dittrich, E. (ed.): Wandel, Wende, Wiederkehr. Transformationen - Gesellschaftlicher Wandel, Würzburg: Ergon, 139-156.

Kollmorgen, R./Schrader, H. (2003): Postsozialistische Transformationen: Gesellschaft, Wirtschaft, Kultur. Theoretische Perspektiven und empirische Befunde, Würzburg: Ergon.

Lewada, J. (1993): Die Sowjetmenschen 1989-1991, München: dtv-dokumente.

Luhmann, N. (1988): Familiarity, Confidence, Trust Problems and Alternatives, in: Gambetta, D. (ed.): Trust - Making and Breaking Co-operative Relations, Oxford: Basil Blackwell, 94-107.

Luhmann, N. (2000): Vertrauen : ein Mechanismus der Reduktion sozialer Komplexität (4. Aufl.), Stuttgart: Lucius und Lucius.

Misztal, B.A. (1996): Trust in Modern Societies. The Search for the Bases of Social Order, New York: Polity Press. 
North, D.C. (1981) Structure and Change in Economic History, New York: WWNorton.

North, D.C. (1990): Institutions, Institutional Change and Economic Performance, Cambridge: Cambrindge University Press.

North, D.C. (1991): Institutions, Journal of Economic Perspectives 5, 97-112.

Olson, M. (1995): Why the Transition form Communism is so Difficult, Eastern Economic Journal 4, 437-461.

Poznanski, K.Z. (ed.) (1995): The Evolution of Transition to Capitalism, San Francisco.

Putnam, R.D. (1993): Making Democracy Work. Civil Traditons in Modern Italy, Princeton: Princeton Univ. Press.

Putnam, R.D. (2000): Bowling Alone: The Collapse and Revival of American Community, New York: Simon and Schuster.

Schrader, H. (2000a): Lombard Houses in Saint Petersburg: Pawning as a Survival Strategy of Low Income Households? (Market, Culture and Society; 10), Münster, Hamburg, London: LIT.

Schrader, H. (2000b): Soziologische Überlegungen zur Problematik des russischen Transformationsprozesses von Wirtschaft und Gesellschaft, in: Schrader, H./Gavra, D./Glagow, M./Kleineberg, M. (eds.): Russland auf dem Weg zur Zivilgesellschaft? Studien zur gesellschaftlichen Transformation in St. Petersburg, Osteuropa: Geschichte, Wirtschaft, Politik Bd. 26, Münster, Hamburg, London: LIT, 50-66.

Schrader, H./Gavra, D./Glagow, M./Kleineberg, M. (eds.) (2000): Russland auf dem Weg zur Zivilgesellschaft? Studien zur gesellschaftlichen Transformation in St. Petersburg. (Osteuropa: Geschichte, Wirtschaft, Politik Bd. 26, Münster, Hamburg, London: LIT.

Simmel, G. (1971): The Stranger, in: Simmel, G. (ed.): On Individuality and Social Forms (original 1908), Chicago: Chicago University Press.

Srubar, I. (1998): Lebenswelt und Transformation: Zur phänomenologischen Analyse gegenwärtiger Gesellschaftsprozesse, in: Müller, K. (ed.) Postsozialistische Krisen. Theoretische Ansätze und empirische Befunde, Opladen: Westdeutscher Verlag, 6887.

Srubar, I. (2001): The longue durée, cyclicity and social transformation, E. Dittrich (ed.) Wandel, Wende, Wiederkehr. Transformationen - Gesellschaftlicher Wandel, Würzburg: Ergon, 51-66.

Staniszkis, J. (1991): The Dynamics of Breakthrough in Eastern Europe. The Polish Experience, Berkeley et al.: University of California Press.

Staniszkis, J. (1995): In Search of a Paradigm of Transformation, in: Wnuk-Lipinski, E. (ed.): After Communism. A Multidisciplinary Approach to Radical Social Change, Warsaw, 19-56.

Stark, D. (1992a): From System Identity to Organizational Diversity - Analyzing Social Change in Eastern Europe, Contemporary Sociology 21, 299-304.

Stark, D. (1992b): The Great Transformation? Social Change in Eastern Europe, Contemporary Sociology 21, 299-304.

Stark, D. (1992c): Path-Dependence and Privatization Strategies in East Central Europe, East European Politics and Society 6, 17-51. 
Stark, D. (1994): Nicht nach Design: Rekombinierte Eigentum im osteuropäischen Kapitalismus, Prokla 94, 127-142.

Tatur, M. (1998): Ökonomische Transformation, Staat und moralische Ressourcen in postsozialistischen Gesellschaften, Prokla 112, 334-374.

Tetzlaff, R. (2000): Globalisierung - "Dritte Welt"-Kulturen zwischen Zukunftsängsten und Aufholhoffnungen, in :Tetzlaff, R. (ed.): Weltkulturen unter Globalisierungsdruck. Erfahrungen und Antworten aus den Kontinenten, Texte der Stiftung Entwicklung und Frieden, Bonn: Dietz, 18-65.

Varese, F. (1994): Is Sicily the Future of Russia? Private Protection and the Rise of the Russian Mafia., Archives Europeennes De Sociologie XXXV, 224-258.

Veselov, Y. (forthc.): Changing Trust in the History of Soviet Society, in: Schrader, H. (ed.): Trust and Social Transformation in Eastern Europe, Münster: LIT and New Brunswick: Transaction.

Witte, G. (1997): Russland als Psychotop, in: Cheauré, E. (ed.): Kultur und Krise. Russland 1987-1997, Berlin: Berlin Verlag.

Zdravomyslova, E./Voronkov, V. (2002): The Informal Public and Soviet Society: Double Morality at Work, Social Research 69, 49-69.

Zloch-Christy, I. (ed.) (1998): Eastern Europe and the World Economy: Challenges of Transition and Globalization, Northampton: Edward Elgar. 